\title{
Aminoacids Absorption by Poblano Chili Crops in Presence of Fulvi-75 Organic Fertilizer
}

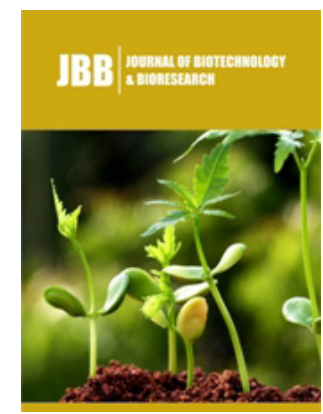

*Corresponding author: Navarrete JM, Faculty of Chemistry, National University of Mexico, Mexico

Submission: 望 February 24, 2020

Published: 侮 May 06, 2020

Volume 2 - Issue 4

How to cite this article: Ramírez $A$, Navarrete JM, Gomez B, Fabila L, Fernández K, Zúñiga MA. Aminoacids Absorption by Poblano Chili Crops in Presence of Fulvi-75 Organic Fertilizer. J Biotech Biores. 2(4). JBB.000541.2020.

Copyright@ Navarrete JM, This article is distributed under the terms of the Creative Commons Attribution 4.0 International License, which permits unrestricted use and redistribution provided that the original author and source are credited.

\author{
Ramírez A, Navarrete JM*, Gomez B, Fabila L, Fernández K and Zúñiga MA \\ Faculty of Chemistry, National University of Mexico, Mexico
}

\begin{abstract}
Fulvi acids are well known as products of organic matter final evolution, which promotes better absorption by vegetables of minerals from the soil. However, aminoacids are one very important factor too in the metabolism of organic matter, either vegetable or animal, but the effect of fertilizers related with aminoacids is not so known. This paper attempts to measure, in terms of percentage, the different absorption of 15 aminoacids by one vegetable (poblano chili), when it is escorted or not by one Mexican fertilizer: Fulvi-75.
\end{abstract}

\section{Introduction}

Fulvi-75, made and distributed by Mexican Company Fitochem (www.fitochem.com. $\mathrm{mx}$ ), was used as fertilizer. It is a compound made by $78.9 \%$ of fulvic acids as percentage of final mixture. Fifteen ${ }^{14} \mathrm{C}$ labelled aminoacids were used: ${ }^{14} \mathrm{C}$ - $\mathrm{L}$ - Amino Acid Mixture, 50 $\mu \mathrm{Ci}$ (1.85MBq) in ethanol: water (2.98), sterile packaged, Perkin-Elmer, Product number NEC850E. Seeds of Mexican vegetable poblano chili were used to test the absorption of mentioned aminoacids, till 21 days later they started their germination. It was considered in this research, that ${ }^{14} \mathrm{C}$ present in the fertilizer, as natural component by its organic cycle, is negligible when compared with ${ }^{14} \mathrm{C}$ labelled aminoacids, and it was considered as background of counts per unit time, from those counts produced by used aminoacids (Table 1), since any way they are absorbed in different proportion when fertilizer is used.

Table 1: ${ }^{14} \mathrm{C}$ labelled aminoacids (Perkin-Elmer product number NEC850E) and percentage present in the mixture)(Total Radioactivity $50 \mu \mathrm{Ci}$ ).

\begin{tabular}{|c|c|c|}
\hline & \multicolumn{3}{|c|}{ Fertilizers } \\
\hline Alanine(13.05\%) & Glutamic acid(16.15\%) & Metionine(0.73\%) \\
\hline Arginine(3,14\%) & Histidine(3.47\%) & Proline $(1.98 \%)$ \\
\hline Aspartic acid(12.48\%) & Isoleucine(6.35\%) & Serine(1.51\%) \\
\hline Fenilalanine(8,93\%) & Leucine(14.94\%) & Tirosine(2.78\%) \\
\hline Gliccine $(3.43 \%)$ & Lisine(2.16\%) & Valine(7.67\%) \\
\hline
\end{tabular}

\section{Experimental}

Two groups with same weight of poblano chili seeds were sown in equal masses of black ground land, in two different plant pots, numered 1 and 2. Once they have started to grow up, both of them were irrigated daily during 21 days with $50 \mathrm{ml}$ of water solution containing the mixture of aminoacids labelled with $11.1 \mathrm{~d} / \mathrm{ml}-\mathrm{m}$ of ${ }^{14} \mathrm{C}$, previously made by diluting $50 \mu \mathrm{Ci}$ of commercial product from Perkin Elmer, The radiochemical Centre, Amersham, England, in 1 liter of water, and then $1 \mathrm{ml}$. of this solution in $100 \mathrm{ml}$. of water, and finally $1 \mathrm{ml}$. of this in another $100 \mathrm{ml}$. of water, to get an activity of $11.1 \mathrm{~d} / \mathrm{m}-\mathrm{ml}$, used to irrigate daily pots 1 and 2 , each one with $50 \mathrm{ml}$. of labelled solution [1,2]. But pot 1 was irrigated also with $50 \mathrm{ml}$. of one solution containing $1 \mathrm{mg} / \mathrm{ml}$ of the organic fertilizer Fulvi-75, produced by Mexican industry Fitochem (www.fitochem.com.mx), while pot 2 was irrigated also with $50 \mathrm{ml}$. of just water. After 21 days of daily irrigation, one little leaf from plants in pots 1 and 2 were cut 
out and weighed. These leaves were then crushed by separate in two small laboratory mortars, which were washed each with $4 \mathrm{ml}$. of solvent used for liquid scintillation detector (Ultima Gold CR,
Perkin-Elmer), and detected during 4 hours, same time considered to obtain the background counts in the system with just liquid scintillation (Figure 1).
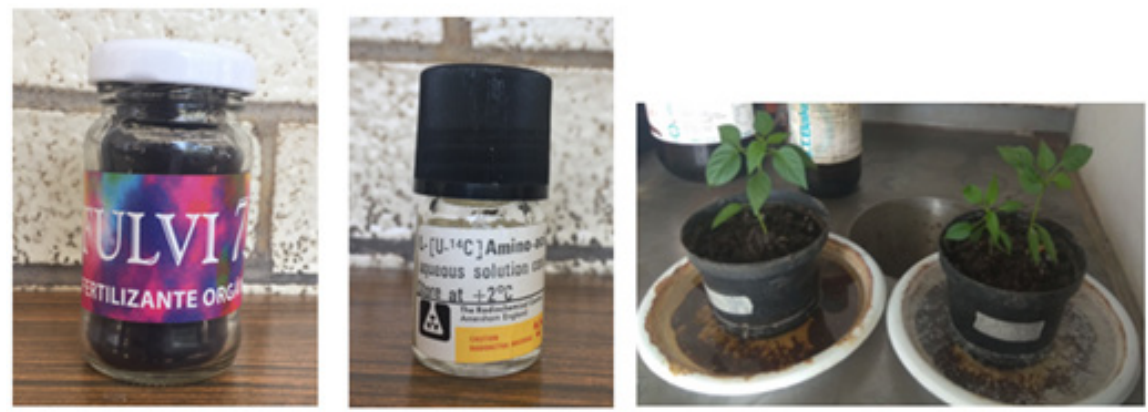

Figure 1: Fulvi-75, 14C labelled aminoacids and small experimental plantation.

\section{Results}

Counts obtained from leaf samples in pot 1 and 2 were corrected by background and they show one statistical variation to $1.6 \%$ and $2.3 \%$ respectively, when divided by counts per time and leaf weight. Then, result from sample 1 was divided by result from sample 2, and a final result equal to 2.76 or $276 \%$ was produced.

\section{Conclusion}

This result seems to proof that pot 1 , irrigated with fulvic acids in water solution, it has absorbed one proportion equal to 2.76 times more labelled aminoacids than pot 2, irrigated with just water, while both pots 1 and 2 were irrigated with same dose of aminoacids.

\section{References}

1. Navarrete JM, Urbina VM, Martínez T, Cabrera L (2005) Autoradiography of mineral ions in green leaves and flowers, absorbed with and without synthetic fulvic acids. J Radioanal Nucl Chem 263: 779-781.

2. Anesio AM, Hollas C, Graneli W, Parry JL (2004) Influence of humic substances on bacterial and viral dynamics in fresh waters. Appl Environ Microbiol 70(8): 4848-4854. 